\title{
Injati — kratka povijest grkokatoličke župe Svete Trojice Vrlika
}

Ivo Mišur*

\begin{abstract}
Sažetak
Slijedom provedenog znanstvenog istraživanja utvrdenog na arhivskim izvorima, članak donosi povijesno-kronološki prikaz zbivanja u grkokatoličkoj župi Svete Trojice u Vrlici od njezina osnutka do de facto gašenja nakon Drugog svjetskog rata. Ovim se radom po prvi puta iznosi detaljan prikaz kretanja broja vjernika te demografska raščlamba župe na temelju stanja duša iz 1887. godine. Pokazano je kako su odluke pokrajinskih i carskih vlasti utjecale na broj vjernika. Razlozi nestanka te malobrojne vjerske zajednice pojašnjeni su u zaključku.

Ključne riječi: Vrlika, grkokatolici, Križevačka eparhija, Crkvena povijest, 19. stoljeće
\end{abstract}

\section{Osnivanje župe}

U Velikom ratu za oslobođenje od turske vlasti (1683.-1699.) iz područja današnje Dalmatinske zagore izbjegli su muslimani, a nove mletačke vlasti na oslobođena područja naselile su nove podanike, katoličke i pravoslavne vjere. Splitski nadbiskup u izvještaju Kongregaciji za širenje vjere 1693. godine piše da je u njegovoj nadbiskupiji bilo petsto pravoslavaca, od toga dvjesto u okolici Sinja i tristo u okolici Vrlike (Bogović, 1982, 88). Od uspostave kršćanske vlasti u Dalmaciji pojavio se problem crkvene jurisdikcije nad pravoslavnim stanovništvom na teritoriju Mletačke Republike. Mlečani su nastojali pravoslavce podčiniti pod crkvene vlasti sa središtem unutar Republike. Pravoslavno svećenstvo tomu se žestoko odupiralo.

U Vrlici su još u 18. stoljeću zabilježeni pojedini slučajevi prelaska pravoslavaca na katoličku vjeru. Vrlički župnik fra Ivan Barbić u svojoj knjizi Vrlički Hrvati odgovaraju piscu $X$. „Vrlike u borbi“ navodi slučajeve iz matične knjige vjenčanih rimokatoličke župe Vrlika iz sredine 18. stoljeća: ${ }^{1}$ Marta, udovica Jovana

* Ivo Mišur, mag.ing.stroj., Zavod za ispitivanje kvalitete d.o.o. Adresa: Gajeva 17, 10000 Zagreb, Hrvatska. E-pošta: ivo.misur@gmail.com

1 Cjelokupne matične knjige s teritorija Republike Hrvatske fotografirane su tijekom 1994. i 1995. godine. Mikrofilmovi se čuvaju u Hrvatskom državnom arhivu u Zagrebu. Na popisima digitali- 
Bačkovića, postala je rimokatolkinja 28. ožujka 1744., a Margarita, kći Mihovila Cvitkovca, prešla je na rimokatoličanstvo 6. studenoga 1746. godine. Isto su učinili Savo Petković Markov 10. srpnja 1747. i Marija p. Rade Bačkovića 20. studenoga 1750. godine. Fratar navodi još četiri slučaja prelaska koji su se dogodili 8. siječnja 1752. te 16 . srpnja, 8. rujna i 30 . studenog 1752 ., ali ne navodi imena obraćenika (Barbić, 1898, 8-9). Riječ je dakle o dobrovoljnim obraćenjima radi sklapanja braka.

Početkom tridesetih godina 19. stoljeća dolazi do vjerskih previranja u dvama selima u Dalmatinskoj zagori, kada su dvojica pravoslavnih svećenika prešla na katoličanstvo i sa sobom poveli dio župljana. Svećenici Kričaka i Baljaka kraj Drniša, Petar Krička i Marko Busović, prihvatili su katoličku vjeru, ali su ostali u svojem istočnom obredu, tj. postali su grkokatolici. Ubrzo se dvojici svećenika pridružio vrlički paroh Pahomije Krička (Pavkovič, 2014). Fra Barbić tvrdi da se na početku osamsto pravoslavca iz Vrlike htjelo pokatoličit te da je »goloruki i siromašni fratar Jukić ${ }^{2}$ pokrenuo pitanje Unije u Vrlici« (Barbić, 1897, 34).

Godine 1834. ustanovljena je grkokatolička župa u Vrlici. U Vrlici su grkokatolici imali specifičan, lokalni naziv — injati (unijati) (Turudić, 2009, 5). Pravoslavni episkop Pantelejmon Živković početkom 1835. godine dobio je izvještaj iz Vrlike u kojem se navodi da se unija počela širiti i u tom mjestu. Živković u pismu upravljenom u Beč vrhovnomu kanceleru 13. travnja 1835. spominje »bučnu scenu « koja se prije nekoliko mjeseci dogodila u Vrlici, što daje naslutiti da su se ubrzo po pojavi nove vjerske zajednice događali incidenti među stanovništvom (Milaš, 1989, 556). Pokrajinska uprava Dalmacije 9. listopada 1835. piše ordinarijatu Pravoslavne crkve da pravoslavni svećenici iz Vrlike i manastira Dragović odbijaju dostaviti matrikularne izvode za sto deset osoba koje su postale grkokatolici u tom kraju. Pravoslavni episkop je protiv toga protestirao te navodi da je od ukupnog broja konvertita preko polovice maloljetnika i djece. Kaluđeri su pod pritiskom na kraju ipak izdali izvode (Milaš, 1989, 562).

U lipnju 1836. u posjet Baljcima, Kričkama i Vrlici po prvi put je došao grkokatolički križevački biskup, pod čijom je crkvenom jurisdikcijom bila grkokatolička Dalmacija. Gavrilo Smičiklas jedanaest je dana proveo obilazeći pastvu, a 8. lipnja 1836. posjetio je Vrliku (Milaš, 1989, 563). Iste godine Smičiklas je za te tri župe osnovao Dalmatinski vikarijat sa sjedištem u Kričkama. U sastavu tog vikarijata bila je i prije osnovana vojna grkokatolička kapelanija sa sjedištem u Zadru (Pavkovič, 2014).

ziranih i mikrofilmiranih matica Vrlike ne postoji knjiga koja obuhvaća godine koje je fra Barbić naveo. Matična knjiga vjenčanih župe Vrlike, koja je još krajem 19. stoljeća bila sačuvana, danas je izgubljena je ili uništena.

2 Fra Antun Jukić bio je nadžupnik Drniša. Šibenska biskupija ga je ovlastila za brigu o pravoslavcima koji žele prijeći na grkokatoličku vjeru. 


\section{Crkva Svete Trojice}

Vrlički grkokatolici, u nedostatku vlastitog objekta, bogoslužje su vršili najprije u rimokatoličkoj crkvi sv. Petra i Pavla na vrličkom groblju (Barbić, 1897, 34). Već 1836. spominje se u pismima episkopa Živkovića grkokatolička kapela u Vrlici (Milaš, 1989, 556). Na mjestu kapele ubrzo je podignuta crkva. Grkokatoličku crkvu Svete Trojice u Vrlici posvetio je 28. svibnja 1844. križevački vladika Gavrilo Smičiklas. Posvećenju je nazočilo mnoštvo grkokatoličkih i rimokatoličkih vjernika, rimokatoličkih svećenika te činovnika. Zbog straha od širenja grkokatoličanstva, isti dan Vrliku je posjetio pravoslavni episkop Jerotej Mutibarić i održao arhijerejsku službu u pravoslavnoj crkvi sv. Nikolaja (Slijepčević, 1991, 600-601).

Crkva Svete Trojice izgrađena je u neoromaničkom stilu. Bila je jednobrodna, položena u smjeru zapad-istok, s time da je oltar bio na istoku. U crkvu se ulazilo iz današnje Ulice 30. svibnja. S prednje strane iznad ulaza nalazio se zvonik s dva zvona. Zvonik je bio kvadratnog oblika s četiri prozora u obliku polukružnih lukova sa svake strane. Iznad drvenih ulaznih vrata bila je mala nadstrešnica. $\mathrm{Na}$ bočnim stranama crkve nalazilo se po pet prozora u obliku polukružnih lukova, na koje su poslije stavljene rešetke. Sa stražnje strane crkve bila je polukružna apsida.

Unutar crkve nalazila se dvadeset jedna ikona (dvije »Prestolne« ikone, dvanaest apostola u osam ikona, dvije ikone Porođenja Isusova, Uspenje Bogorodice, Obrezanje, Sv. Petar i Pavao, Uskrsnuće, Posljednja večera, Sv. Trojstvo, Preobraženje) (AKE 488/1882).

Krajem 19. stoljeća crkva je bila zapuštena i pogibeljna za obavljanje obreda u njoj. Razloge lošemu stanju crkve pronalazimo u pismima vrličkih župnika i dalmatinskih vikara koja su pisali križevačkomu biskupu. Vikar Vladislav Laboš piše 4. lipnja 1888. da je don Nikola Segedi dopustio Josi Kulišiću da sagradi sušu za akumulaciju vode. Voda je otjecala uz zid crkve od 1883. do 1886. godine. Kulišić je uklonio sušu na zahtjeve župnika. Međutim, kroz te četiri godine voda je otjecala uz južni zid crkve i time omekšala tlo, što je prouzročilo da je temeljni kamen južnog zida crkve potonuo (AKE br. 329/1888.). Petar Stanić 24. prosinca 1887. piše da je crkva zadnji put popravljena u lipnju 1877. i da je zid počeo pucati u prosincu 1884. godine. U listopadu 1887. zid se nakon obilne kiše pomaknuo za centimetar. Krov je također curio na sve strane te su 1887. poprečne i uzdužne grede sagnjile. Krov se nagnuo na južnu stranu. Uslijed otklona južnog zida popucao je i poprečni zid nad svetištem, i to okomito (AKE br. 813/1887).

Crkva je bila u jako lošem stanju te se činilo da je popravak nemoguć jer je ipak bilo riječ o temelju. Namjesništvo se bojalo da bi se crkva nakon popravka mogla opet srušiti, što bi bio nepotreban trošak. Troškovi popravka procjenjivali su se na tri-četiri tisuće forinti (AKE br. 638/1888). Pojavila se ideja o gradnji nove crkve na drugoj lokaciji, koja je napuštena nakon što se utvrdilo da je uklanjanjem suše prestalo propadanje crkve (AKE br. 329/1888). Stoga se kao 
rješenje predlagala gradnja nove crkve na mjestu stare, koja bi se srušila. Procjenjivalo se da bi nova crkva koštala deset tisuća forinti (AKE br. 638/1888).

U tom razdoblju dalmatinsko pokrajinsko Namjesništvo sa sjedištem u Zadru nije bilo sklono grkokatolicima. Godine 1890. predložili su napuštanje župe (AKE br. 712 i 747/1890), a 1895. rušenje crkve (AKE br. 871 i 1063/1895). Duhovni stol se 1892. za pomoć obratio državnomu ministru Gauču, koji također nije imao sluha. Nije pristao na gradnju nove crkve, nego je predložio da se jedna soba u župnoj kući uredi za bogoslužje (AKE br. 770/1892). Iste godine odlučeno je da se Križevačka eparhija obrati samomu caru za pitanje crkve (AKE br. 800/1892). Kulišić je očito koristio svoje političke veze u nastojanjima da se crkva poruši, na čijem je mjestu planirao izgraditi konjušnicu (Barbić, 1898, 84). Vladika Drohobeczky uspio je obnoviti crkvu 1895. godine. Izvođač radova bio je građevinar Stagni, a ukupna cijena radova i materijala iznosila je 4.531 forinti (AKE br. 728/1897). Šteta koju je voda nanijela bila je očito nepopravljiva jer se ponovno 1915. šalje molba Namjesništvu u Zadru za popravak crkve i župne kuće (AKE br. 467 i 534/1915). Biskup je 1922. poslao financijsku pomoć za popravak crkve (AKE br. 473/1922), a 1927. podignut je zajam za obnovu župne kuće (AKE br. 2003/1927). Nakon smrti posljednjeg vrličkog grkokatoličkog župnika Malića, ključevi crkve su 1923. godine predani rimokatoličkomu župniku don Ivanu Menđušiću (AKE br. 1222/1923). Propadanje crkve nastavilo se, a nakon Drugog svjetskog rata dva zvona su odnesena u Križevce. Općina je 1950-ih kupila crkvu i planirala je preurediti za prosvjetne svrhe (Roca, 1962, 25). Crkva je ozbiljnije stradala u potresu 1970. godine, kada se srušio krov, nakon čega su je vlasti do kraja uklonile (Turudić, 2009, 5). Na mjestu crkve danas se nalazi dječje igralište. Zemljište u blizini crkve bilo je predmet parnice između općine i župe (AKE br. 742/1897).

\section{Pritisci i mito}

U cijeloj knjizi Pravoslavna Dalmacija Nikodim Milaš $\check{5}^{3}$ piše da su pravoslavci u Dalmaciji prelazili u grkokatolike nasilnim putem i podmićivanjem. Ipak, navodi imenom i prezimenom samo jedan takav primjer u Vrlici. Riječ je o Jovanu Kosturu koji je podmićen, ali se vrlo brzo vratio na pravoslavlje (Milaš, 1989, 556). To dokazuje da je pojava grkokatolika u Vrlici stvar slobodne volje i iskrenih vjerskih osjećaja pojedinaca.

Pravoslavni episkop Živković u već spomenutom pismu iz 1835. godine spominje da je vrlički paroh Nicefor Kovačević dijelio žito i drugu pomoć samo svojim vjernicima koji su izjavili da neće u uniju. Radi takvog ponašanja pretor iz Sinja mu je zaprijetio da će izgubiti parohiju. Živković je optužio vrličkog općinskog načelnika Poletija i serdara Šupuka da nasilno »vrše unijaćenje « (Milaš, 1989, 558). Posebno je optužio obitelj Novaković za proganjanje pravoslavnih

3 Nikodim Milaš bio je pravoslavni episkop i političar u 19. stoljeću. Porijeklom po ocu bio je Vrličanin. 
vjernika. ${ }^{4}$ Navodi se dalje da su dva Novakovića s grkokatoličkim svećenikom Bubanovićem uspjeli nagovoriti Jovana Kostura na prihvaćanje unije. Živković ih optužuje da su Kostura podmitili te ga ovlastili da razdaje žito i vino te druge potrepštine pravoslavnima koji postanu grkokatolici. Obećali su mu bogatu naknadu od vlade za sve ono što od svojeg imetka izda na spomenutu svrhu. Živković dalje navodi da Kostur nije uspio nikoga nagovoriti na uniju. U trenutku pisanja pisma navedeni Jovan Kostur očito se povratio na pravoslavlje jer »za Uniju neće ni da čuje « (Milaš, 1989, 556). Živković piše da je u Vrlici trenutačno jedan grkokatolički svećenik za čije boravljenje on spominje da je »nezakonito i neopravdano« te pogibeljno za sigurnost i mir (Milaš, 1989, 556).

Za razliku od pokatoličavanja, izvori pokazuju da je prepravoslavljivanje (povratak grkokatolika u pravoslavlje) u Vrlici ostvarivano podmićivanjem i prijetnjama. Fra Barbić spominje da je u vrličkoj općini postojala isprava od 7. srpnja 1835. na kojoj je pisalo: »Aleksa Šmanja pounijatio se je god. 1833. pred svjedocima Don Dulikravićem, ${ }^{5}$ Serdarom Šupukom i Antom Poleti. On je vjerno bio privržen srcem i dušom uniji tako da je često pristupao na sv. Sakramente i za neko vrijeme u sv. Petra gdje se unijatima vršila leturgija obavljao je bez svake plaće dužnost sakreštana.«Aleksa se poslije zaljubio u Cvijetu Gjurgjević koja je bila pravoslavka. Pravoslavni župnik Nicefor Kovačević nagovorio ga je da se vjenčaju u pravoslavnoj crkvi (Barbić, 1898, 34).

O pravoslavnom prozelitizmu pisao je grkokatolički svećenik Laboš. U jednom pismu 23. ožujka 1859. spominje da je njegov vjernik Krstan Škrbo nagovoren i podmićen da postane pravoslavac. Spominje i Ivanicu, ženu Jovana Škrbića, koja da mu se požalila da ju je Kalinić ${ }^{6}$ nagovarao da prijeđe na pravoslavnu vjeru s djecom te joj obećao »dvije kvarte kukuruza« (Barbić, 1898, 44-45). Jakov Ćudina u svojoj monografiji o Vrlici spominje Nikolu Škrbu, koji se vratio pod stare dane u pravoslavlje i umro 1863. godine (Barbić, 1898, 221).

Osim davanja novaca i žita, grkokatolicima su se nudili i poslovi. Pravoslavni župnik Kornelije Pavasović dao je posao zvonara siromašnomu postolaru Ivi Đukiću uz uvjet da se odrekne grkokatoličke vjere i postane pravoslavac. Tako je Pavasović za 15 forinti mjesečno, koliko je iznosila Đukićeva plaća, pridobio novog vjernika (Barbić, 1898, 226-227).

Dana 26. rujna 1871. svećenik Latković piše svojemu duhovnomu stolu u Križevce da se Petar Škrbić pok. Jovana iz Garjaka s majkom Ivanicom, staricom od šezdeset godina, »od Unije odmetnuo i u schismu upao«. Bogati pravoslavci su ga sa svećenikom potplatili 25. rujna 1871. u vrijeme kad se planirao oženiti. Škr-

4 Obitelj Novaković hrvatska je rimokatolička obitelj koja se tijekom druge polovice 19. stoljeća sukobljavala sa srpskom obitelji Kulišić, iz koje su potekli vrlički načelnici Krsto (otac) i Joso (sin). Sukob dviju obitelji bio je i vjerskog i nacionalnog karaktera te su Novakovići u zadnjim desetljećima 19. stoljeća u Vrlici bili nositelji hrvatske političke misli, a Kulišići srpske.

5 Milaš navodi da je Dulikravić postavljen za paroha u Vrlici nakon bijega Pahomija Kričke, tj. ubojstva Petra Kričke. Ubojstvo se dogodilo 1. ožujka 1834. godine. Fra Ivan Barbić navodi dokument u kojem je Dulikravić prisustovao obraćenju Aleksa Šmanja 1833. godine. Dulikravić je bio i vojni kapelan pa je moguće da je službu prije Vrlike obavljao u Zadru.

6 Antun Kalinić, općinski dužnosnik, rimokatolik po vjeri, koji je podržavao Josu Kulišića. 
bić je izrazio želju da prijeđe na pravoslavnu vjeru, ali je već 10. studenog 1871. došao s dvama svjedocima da bi se povratio u »grčko-sjedinjenu vjeru«. Bio je pravoslavac toliko dugo koliko je bilo potrebno da mu pravoslavci daju novce za vjenčanje (Barbić, 1898, 44-46).

Grkokatolički križevački vladika Julije Drohobeczky posjetio je Vrliku 22. studenog 1895. prilikom obnove crkve za koju je osigurao novac. Tom prigodom, u čast biskupu, Milan Begović napisao je pjesmu koja je objavljena u Narodnom listu br. 80 dana 5. listopada 1895. (Barbić, 1898, 211). Malo prije dolaska vladike dvanaest obitelji (pedesetak osoba) iz Vrlike prijavilo se za prelazak na katoličku vjeru. Na blagoslovu obnovljene crkve svih dvanaest obitelji bilo je tada na okupu. Tadašnji župnik Ilija Malić nije žurio s upisom novih vjernika u crkvene knjige i htio se uvjeriti u iskrene namjere navedenih osoba. Prošao je i Božić, a obiteljima nije odobren prelazak. To odlaganje iskoristili su pravoslavci. Pravoslavni vladika Nikodim Milaš dolazio je u Vrliku zajedno s arhimandritom Jovićem te jednim profesorom bogoslovije iz Srbije. Odgovorali su i prijetili onima koji su htjeli postati grkokatolicima. Milaš je rekao: »muhe će crkati, koje budu na unijate padale «(Barbić, 1898, 225)! Akcije pravoslavnih svećenika su urodile plodom te je većina odustala od prijelaza. Ostao je vjeran samo Pilip Kovačević sa šesteročlanom obitelji. Kovačević je poslije molio Križevačku udovičku zakladu za 160 forinti pozajmice, ali su ga nakon godinu dana odbili (Barbić, 1898, 225-226).

U samoj Vrlici grkokatolički svećenici često su bili uznemiravani od strane pravoslavaca. Grkokatolički župnik Poturičić žalio se da »ne može pohoditi svoje župljane bez pogibli života« (Barbić, 1898, 221). Don Marko Stanić pisao je 21. svibnja 1849. da su 11. svibnja 1849. pod pritiskom Krste Kulišića i Tane Ristovića trojica njegovih vjernika iz Maovica, Ilija Gjurić, Sava Gjurić i Nikola Primetica, pijani i podmićeni došli k njemu htijući se vratiti u pravoslavnu vjeru. Nastala je incidentna situacija u kojoj su vrijeđali župnika i grkokatolike. Htjeli su iznijeti ikone iz grkokatoličke crkve i odnijeti ih u pravoslavnu (Barbić, 1898, 40-41). Don Andrija Laboš 14. travnja 1857. piše općini da urgira u vezi s nalogom što ga je službenik carske i kraljevske prefekture dalo Krsti Kulišiću da »ukloni đubre što ga je nagomilao kraj crkve sv. Trojice« (Barbić, 1898, 43). Crkva Svete Trojice bila je pokraj kuće obitelji Kulišić koja je dala dva općinska načelnika, Krstu i Josu, oca i sina. Između crkve i kuće nalazio se prolaz od četiri metra širine. Krsto Kulišić bio je veliki neprijatelj novonastale vjerske zajednice. U jednom od svojih pisama hvalio se »utamnio sam Unijate« (Barbić, 1898, 43). Novi vrlički općinski načelnik, baš kao i njegov otac Krsto, nikako se nije mogao pomiriti s postojanjem grkokatolika u Vrlici. Jozo Kulišić tako 1888. godine piše da »Srbi mrze unijatstvo, dušmani su mu daklen zakleti, nepomirljivi« (Barbić, 1898, 222).

Plaća grkokatoličkih svećenika dugo je vremena iznosila 200 forinti godišnje. Kasnije je porasla na 300 forinti, a poslije 1880. dohodak je bio 500 forinti (Barbić, 1898, 39). Poradi financijskih poteškoća u jednom dijelu župne kuće živio je župnik s obitelji, a drugi je dio iznajmljivan podstanarima (AKE br. 218/1887). O lošem financijskom stanju grkokatoličke župe i skromnom životu njihovih župni- 
ka svjedoče brojne molbenice za novčanu pomoć iz arhiva Križevačke eparhije. Time se najbolje pokazuje neutemeljenost pravoslavnih prozivanja za davanje prozelitističkog mita grkokatoličkih svećenika.

Grkokatolički svećenici bili su ugledni i aktivni članovi mjesne zajednice. Osim Malića, o kojem će biti više riječi poslije, u kulturnom radu u Vrlici istaknuo se i svećenik Nikola Segedi, koji je 1883. osnovao pjevački zbor (Barbić, 1898, 83). Don Petar Stanić je tijekom boravka u Vrlici bio povjerenik Kninskog starinarskog društva te je surađivao s poznatim hrvatskim arheolozima don Franom Bulićem i fra Lujom Marunom (Anon., 2012c). Stanić je 1890. i 1891. obavljao arheološka istraživanja na položaju Crkvina u Gornjim Koljanima, gdje je otkrio ostatke starohrvatske crkve (Jelovina, 1976, 50). Don Đuro Smičiklas, koji je bio vrlički župnik od 1842. do 1846., poslije je postao križevački grkokatolički biskup (Anon., 2012a).

Nasuprot stalnim sukobima s pravoslavnim svećenicima, odnosi grkokatoličkih i rimokatoličkih župnika bili su jako dobri. Tomu najbolje svjedoči činjenica da je grkokatolički svećenik rimokatoličkomu pomagao obavljati službu (ispovijedi, sprovodi, mise), a ovaj bi mu financijski pripomagao (Barbić, 1898, 64). Dok je crkva Svete Trojice bila u ruševnom stanju od 1886. do 1888., grkokatolička liturgija služila se u rimokatoličkoj crkvi Gospe Ružarice (AKE br. 574/1888).

Sve to pokazuje da su u Vrlici pod pritiskom bili grkokatolici, a ne pravoslavci. Stalni napadi i provokacije rezultirali su i otvorenim stavljanjem grkokatoličkih svećenika u Vrlici na stranu hrvatskog nacionalnog preporoda, nasuprot srpskog.

\section{Broj vjernika}

Poradi pritisaka i podmićivanja pravoslavnih svećenika i općinskih načelnika, dio vjernika vraćao se na pravoslavnu vjeru. Zbog toga broj vrličkih grkokatolika stalno varira. Neki izvori navode brojku od tristo vjernika, za koju nema potvrde u dostupnim izvorima (Turudić, 2009, 5). Fra Barbić piše u svojoj knjizi da je u prvom popisu u Vrlici bilo sto šezdeset grkokatolika, za što također ne navodi izvor (Barbić, 1898, 32).

U Šematizmu Križevačke eparhije nalaze se brojčani podatci o broju vjernika pojedine župe razvrstani po mjestima prebivališta. Dostupna su izdanja za sljedeće godine : 1838., 1840., 1841., 1846., 1850., 1852., 1854., 1859. i 1868. Broj vjernika u župi se također može pronaći u „stanjima duša“ koja je popisivao župnik. U arhivu se nalaze spisi župe od 1874. do 1932. godine, kada su prodane neke nekretnine. Prema inventaru Križevačke eparhije sačuvana su „stanja duša“ iz sljedećih godina: 1874., 1876., 1885., 1887., 1890. i 1893.7 Svi popisi su u Križevcima, osim onog iz 1887., koji se nalazi u Zagrebu.

7 Unatoč tomu što su u inventaru upisani kao „stanja duša“, većinom je riječ o brojčanim izvještajima koja su vrlički župnici slali križevačkomu biskupu. Cjeloviti popisi s imenima župljana postoje samo za 1887. i 1890. godinu. Za demografsku raščlambu odabran je popis iz 1887. jer je u njemu, za razliku od onoga iz 1890., upisana dob skoro svih župljana. 
Ukupan broj vjernika je iz godine u godinu varirao. Godine 1838. najviše vjernika bilo je Civljanama (27), Kukru (25) i Garjaku (19). Od 1838. do sredine 1840-ih ukupan broj vjernika relativno je stabilan i kreće se od sto dvadeset šest do sto trideset tri. Unatoč stabilnosti ukupnog broja, iz kretanja broja vjernika u pojedinim selima zamjetni su rezultati agitiranja i prozelitizam. U promatranom razdoblju u Civljanama, Šušnjaru i Koljanama došlo je do pada broja vjernika. Do porasta je došlo u Vrlici, Kukru, Podosoju, Garajaku i Maovicama. Od drugog popisa napravljenog 1846. vjernici iz Šušnjara popisivani su pod Garjakom. U popisu iz 1840. upisana su dvojica vjernika (Kaštel i Benkovac) s boravištem izvan vrličkog kotara.

Tablica 1. Prikaz brojčanog stanja grkokatoličke župe Vrlika od 1838. do 1890. godine (izvori: Šematizam Križevačke eparhije i Arhiv Križevačke eparhije)

\begin{tabular}{|c|c|c|c|c|c|c|c|c|c|c|c|c|c|c|c|}
\hline & 1838 & 1840. & 1841. & 1846 & 1850. & 1851. & 1852. & 1854 & 1859. & 1868. & 1874 & 1876. & 1884. & 1887. & 1890. \\
\hline Vrlika & 17 & 19 & 19 & 19 & 23 & 25 & 30 & 25 & 29 & 37 & 30 & 28 & 25 & 21 & 21 \\
\hline Civljane & 27 & 20 & 21 & 19 & 16 & 14 & 13 & 14 & 1 & 2 & & & & & \\
\hline Kukar & 25 & 30 & 30 & 31 & 39 & 32 & 33 & 28 & 12 & 17 & 4 & 5 & & & \\
\hline Podosoje & 6 & 6 & 6 & 10 & 23 & 21 & 23 & 23 & 9 & 13 & 1 & 1 & 1 & 1 & 1 \\
\hline Šušnar & 13 & 8 & 9 & & & & & & & & & & & & \\
\hline Garjak & 19 & 19 & 13 & 25 & 31 & 21 & 26 & 26 & 14 & 15 & 4 & 4 & 5 & 5 & \\
\hline Maovice & 14 & 13 & 21 & 20 & 25 & 21 & 22 & 21 & 18 & 17 & 7 & 6 & 4 & 4 & 5 \\
\hline Koljane & 12 & 9 & 9 & 9 & 8 & 7 & 7 & 7 & 1 & 3 & & & & & \\
\hline \begin{tabular}{c} 
Otišić \\
\hline Knin
\end{tabular} & & 1 & & & 6 & 6 & 6 & 5 & 2 & 2 & & & & & \\
\hline Kaštel & & 1 & & & & & & & & & & & & & \\
\hline Benkovac & & & & & & & & & & & & & & 2 & \\
\hline \begin{tabular}{c} 
Split \\
\hline Mostar
\end{tabular} & & & & & & & & & & & & & 2 & \\
\hline $\begin{array}{c}\text { Ukupno } \\
\text { u kotaru } \\
\text { Vrlika }\end{array}$ & 133 & 124 & 128 & 133 & 171 & 147 & 160 & 149 & 86 & 106 & 46 & 44 & 35 & 31 & 26 \\
\hline UKUPNO & 133 & 126 & 128 & 133 & 171 & 147 & 160 & 149 & 86 & 106 & 46 & 44 & 35 & 38 & 26 \\
\hline
\end{tabular}

Najveći broj grkokatolika u vrličkom kotaru zabilježen je 1850. godine. U samo nekoliko godina broj župljana se s broja sto trideset tri popeo na rekordnih sto sedamdeset jedan. U odnosu na prijašnji šematizam taj porast je ostvaren ponajprije konvertitima iz Podosoja (13), Kukra (8), Garjaka (6), Maovica (5) i Vrlike (4). U Civljanama su upisana trojica vjernika manje nego na prošlom popisu. Prvi put je u popisu kao zasebna cjelina upisan i Otišić.

Idući šematizam izrađen je godinu dana poslije. U vrličkom kotaru zateklo se dvadeset četiri vjernika manje. Najveći pad dogodio se u Garjaku (10) i Kukru (7).

Godine 1852. evidentirano je sto šezdeset grkokatolika u grkokatoličkoj župi Vrlika. U Vrlici i Garjaku zabilježeno je po pet novih vjernika. 
Dvije godine poslije došlo je do ponovnog opadanja broja unijata. Upisano je sto četrdeset devet vjernika te godine. U Vrlici se pet vjernika ispisalo iz župe. Vjerojatno je riječ o pet vjernika koji su pristupili prije dvije godine. U Kukru je popisano pet vjernika manje.

Godine 1859. zabilježen je drastičan pad broja vjernika od $42 \%$, sa sto četrdest devet na osamdeset šest. Najveći pad dogodio se u Civljanama, gdje se kroz godine relativno stabilna zajednica od petnaestak ljudi svela na jednog čovjeka. U Garjaku i Kukru broj ljudi je prepolovljen. Jedini porast je popisan u Vrlici.

Već 1868. u šematizmu je popisano sto šest grkokatolika u vrličkoj župi. U svim mjestima, osim Otišiću zabilježeno je povećanje broja vjernika, od kojih prednjači Vrlika s osam novih župljana.

Drastičan pad broja vjernika vidljiv je u izvještaju vrličkog župnika koji je poslan biskupu 1874. godine. Vrlička grkokatolička župa svela se na svega četrdeset šest vjernika. Od prošlog popisa grkokatolici su nestali iz Civljana, Koljana i Otišića. U Kukru, Podosoju, Garjaku i Maovicama grkokatolička zajednica svela se na po jednu obitelj i pojedince.

U župničkim izvještajima iz 1876. i 1884. te u Stanjima duša iz 1887. i 1890. vidljivo je stalno opadanje broja vjernika u vrličkom kotaru.

Tijekom godina se kao kontinuirano brojčano najstabilnije mjesto župe pokazala sama Vrlika. Razlog treba tražiti u samoj lokaciji crkve i blizini župnika. Tijekom 19. stoljeća po udjelu broja vjernika prednjačili su Kukar, Maovice, Garjak (sa Šušnjarom) te poslije 1874. Vrlika.

Zamjetan brojčani rast i pad broja vjernika u rasponu nekoliko godina pokazuje da su pojedine osobe koje su mijenjale vjeru iz katoličke u pravoslavnu i obrnuto to činile iz koristoljubivih razloga. Za novčanu podršku katoličkomu prozelitizmu Milaš je prokazao braću Novaković, a za davanje mita za prelazak na pravoslavlje Krsto i Joso Kulišić i pravoslavni kaluđeri (Kornelije Pavasović). Osim financijske podrške povratak na pravoslavlje je ostvarivan uznemiravanjem grkokatolika i njihova župnika.

U „stanju duša“ izrađenom na Badnjak 1887. godine vidljiva su demografska obilježja grkokatoličke župe Svete Trojice u Vrlici. Popisano je trideset osam osoba. Popis se nalazi u arhivu Križevačke eparhije u odjelu u Zagrebu u Ćirilometodskoj ulici. Dokument naziva Popis duša župe grčkokatoličke u Vrlici zaveden je u eparhijskom arhivu pod brojem 175. Ispod naslova se nalazi opaska da u Vrlici postoji rimokatolička župa s tri i pol tisuće duša. Popis je izradio don Petar Stanić, čiji se potpis nalazi na kraju dokumenta. Župljani su popisani brojevima od 1 do 38. Svaka obitelj je dobila svoje slovo abecede te je popisano četrnaest domaćinstava označenih slovima od a do n. Prva osoba na popisu je uvijek otac, odnosno glava obitelji, nakon njega slijedi žena, eventualno majka glave obitelji te djeca. Uz ime i prezime naveden je datum rođenja te vjenčanja. Uz imena žena upisano je i djevojačko prezime te mjesto podrijetla.

Jedanaest osoba ili $28 \%$ župljana bilo je maloljetno. Sedam župljana živjelo je izvan vrličkog kotara (po dvoje u Benkovcu, Splitu i Mostaru, a jedno u Kninu). 
Od trideset jednog župljana najviše ih je bilo u Vrlici (21), Garjak (5), Maovice

(4) i Podosoje (1).

Bilo je pet samačkih domaćinstava. Također je bilo pet bračnih parova bez djece te četiri obitelji s prosječnim brojem od 3,75 djece (sedam, četiri, tri i jedno). Samo je jedan par bio nevjenčan i imao izvanbračno dijete.

Za šest osoba nije naveden datum rođenja ni dob, od kojih su dvoje imali prebivalište izvan kotara. Prosječna starosna dob župe iznosila je 29 godina, s tim da je starosna dob župljana unutar kotara 28,62, a onih izvan 31 godinu. Najstarija je bila Kata Paspalj rođena 1809. godine, a najmlađa Marija Gjukić, koja je u trenutku sastavljanja popisa imala devet mjeseci.

U župi je omjer muškaraca i žena bio 18 : 20 u korist žena, odnosno 48\% : 52\%. Unutar samog kotara bilo je $15: 16$ u korist žena.

Usporedimo li podatke popisa stanovništva iz 1890. i stanje duša iz 1887. grkokatolici su tada činili $0,004 \%$ stanovništva kotara te 2,5\% stanovništva same Vrlike. Usporedimo li na isti način podatke iz šematizma iz 1859. i popisa 1857. vidi se da je udio unijata u kotaru 1,45\%, a u Vrlici 4,5\%. Godine 1869. (prema šematizmu 1868.) grkokatolici su činili 4,9\% Vrličana i 1,7\% populacije kotara.

Glavni razlog velikog broja prelazaka iz jedne vjere u drugu, pogotovo nakon 1850., bio je carski patent i jedna ministarska odluka koje su olakšale promjenu vjere. Naime, 30. siječnja 1849. izdana je ministarska naredba koja je olakšala prelazak i povratak na pravoslavlje. Ubrzo nakon toga, 4. ožujka 1849., izdan je carski patent kojim se pravoslavlju priznaje ravnopravnost sa svim drugim vjerama u Habsburškoj Monarhiji. Tim odredbama omogućen je brži i lakši povratak u pravoslavlje. Do tada je vrijedio dekret od 31. srpnja 1833. br. 12533/2240 kojim je kanon 318. kanonskog prava Katoličke crkve proglašen kao norma koja je zakonski valjana pri promjeni vjere. Prema tom kanonu za prelazak na katoličku vjeru bila je dovoljna izjava vjernika pred katoličkim župnikom.

Grkokatolika je, osim u samoj Vrlici, bilo i u okolnim selima: Civljanima, Kukru, Podosoju, Šušnjaru (dio Garjaka), Garjaku, Maovicama, Koljanima i Otišiću. Grkokatoličke obitelji bile su Bačković, Begović, Paspalj, Petrović, Škrbić, Šmanja i Vujnović (AKE br. 814/1887). Najpoznatiji i najbrojniji bili su Gjukići, čiji potomci danas ne žive u mjestu svojih predaka, ali su ostali vjerni svojoj vjeri i obredu. Zasad jedini Vrličanin koji je postao grkokatolički svećenik je don Ilija Gjukić. Upravljao je župom Stojdrage od 1877. do 1880. godine (Anon.). U toj župi je umro te je tamo i pokopan (Pavković, 1980, 7). U Žumberačkom krijesu iz 1980. objavljena su sjećanja bivšeg sjemeništarca Stjepana Đukića (Gjukića), koji se rodio u Vrlici, a živio je u Zagrebu. Poznati žumberački povjesničar Milko Predović planirao je napisati monografiju o obitelji Đukić u kojoj bi najviše pozornosti pridao don Iliji, Stjepanu i Milanu Đukiću. 


\section{Gašenje župe i don Ilija Malić, posljednji grkokatolički župnik u Vrlici}

Župnici grkokatoličke župe Vrlika bili su redom: Pahomije Krička (nakon ubojstva Petra Kričke pobjegao u Hrvatsku), Đuro Dulikravić, (kapelan Ljubatović), ${ }^{8}$ Bazilije Poturičić, Đuro Smičiklas, Nikola Hranilović, Daniel Garapić, Andrija Laboš, Mihael Latković, I. Popović, Nikola Segedi, Petar Stanić, Ilija Malić (1893.-1921.). Malić je bio zadnji grkokatolički župnik u Vrlici. Nakon njega župom su upravljali vikari Dalmatinskog vikarijata sa sjedištem u Kričkama.

Ilija Malić rođen je 15. rujna 1867. u Malićima u Žumberku. S njim je u novoj župi živjela i njegova obitelj, a barem jedno dijete mu se rodilo u Vrlici. Došao je u Vrliku 15. svibnja 1893. godine. Neupućen u zbivanja i političku situaciju u svojem novom prebivalištu, najprije se učlanio u čitaonicu Sloga, u kojoj je glavnu riječ vodio Jozo Kulišić. Vrlo brzo je istupio iz Sloge, a potom postao članom novoosnovane Hrvatske čitaonice (Barbić, 1898, 178). Vlasti su mu uskratile plaću jer nije bio austrijski državljanin (Barbić, 1898, 47). Naime, rođen je Banovini Hrvatskoj, koja je tada bila dio ugarskog dijela Monarhije, a Dalmacija je bila dio austrijskog dijela države. Poslao je zahtjev za državljanstvom, ali je odbijen. Aktivan je u političkom životu mjesta i sudjeluje kao svjedok u sudskom procesu protiv problematičnog seoskog liječnika Trojanovića, koji je bio agitator srpske nacionalne ideje. Joso Kulišić navodi da je Malić bio na čelu hrvatski orijentiranih prosvjednika protiv svečanosti prigodom proslave njegova odlikovanja od strane ruskog cara (Barbić, 1898, 168). Nepoznati autor, najvjerojatnije Malićevi politički neprijatelji, pismeno su se žalili križevačkomu vladiki na njega (Barbić, 1898, 183). Živio je skromno, o čemu svjedoči da je 1919. tražio od biskupa financijsku potporu za sina Milana (AKE 1073 i 1074/1919). Pokopan je 1921. na katoličkom groblju sv. Petra i Pavla u Vrlici (Kozlica, 2015, 326). Njegovoj udovici dopušten je ostanak u župnoj kući do imenovanja novog župnika (AKE 784/1922).

Propašću Austro-Ugarske grkokatolici dolaze u još nepovoljniji položaj u novoj državi Kraljevstvu SHS (poslije Jugoslaviji), gdje je kralj kao i relativna većina stanovništva bila pravoslavna. Vrličku grkokatoličku župu napadale su režimske novine Država, koje su huškale na oduzimanje crkve i župnog stana (Šimrak, 1925, 89-92). Da su postojale ozbiljne namjere u prenamjenu župnih objekata svjedoči molba žandarmerije iz Splita iz 1924., koja je tražila da joj se da u najam župna kuća (AKE br. 1483/1924). Neposredno prije početka Drugog svjetskog rata u vrličkom kotaru živjelo je petnaest vjernika (Draganović, 1939, 112).

Nakon smrti Ilije Malića, za administratora dalmatinskih župa 1924. postavljen je don Janko Heraković. On je prije upada četnika, koji su ga planirali ubiti, pobjegao u Križevce u studenom 1942. godine. Sa sobom je ponio matične knjige župe Vrlika, koje su danas zagubljene. Od župnog arhiva uspjela su se sačuvati

8 Taj podatak navodi Milaš (1989.) u svojoj knjizi na 563. stranici, a u arhivu Križevačke eparhije nigdje se ne spominje Ljubatović kao kapelan župe Vrlika. 
stanja duša popisanih, koja se danas nalaze u arhivu Križevačke eparhije. Heraković se u kolovozu nakratko vratio u Dalmaciju te obišao Vrliku, Kričke i Baljke. U izvještaju duhovnomu stolu napisao je da su župni dvor i crkva u Vrlici u ruševinama (Anon., 2012b).

Ta mala vjerska zajednica nestala je nakon Drugog svjetskog rata. Zamiranje župe označila su tri događaja: smrt zadnjeg župnika don Ilije Malića, smrt posljednjeg grkokatolika u Vrlici 1952. (Roca, 1962, 25) i rušenje crkve 1970. godine.

\section{Zaključak}

Vrlički injati bili su malobrojna vjerska zajednica nastala u valu vjerskih previranja u susjednim drniškim selima. U specifičnim okolnostima opstali su sto devetnaest godina, od 1833. do 1952., kada izumiru. Za nestanak vrličkih grkokatolika glavni krivci su općinski čelnici (Krsto i Joso Kulišić) te pravoslavni svećenici koji su činili sve kako bi napakostili grkokatoličkim svećenicima i njihovoj crkvi te preoteli vjernike svim mogućim metodama. Dio krivnje snosi i država, odnosno dalmatinska pokrajinska vlast, koja ih nije zaštitila i osigurala normalan rad župe. Odbijanjem davanja državljanstva župniku, uskraćivanjem plaće, zabranom popravka i predlaganjem rušenja crkve pokazalo se da dalmatinska vlada nije bila sklona vrličkim grkokatolicima. Iza takvog odnosa Namjesništva prema toj župi mogu se naslutiti nastojanja Jose Kulišića koji je bio utjecajan političar. Treći razlog je siromaštvo župe tijekom cijelog njezina trajanja. Crkva i župna kuća stalno su bili u ruševnom stanju, a župnici su pisali molbe za financijskom pomoći. Nemogućnost održavanja mise u grkokatoličkoj crkvi (od 1886. do 1888.) također je utjecalo na opadanje broja vjernika. Četvrti razlog nestanka grkokatolika u Vrlici velika je geografska udaljenost od duhovnog središta, Križevaca. Ionako malobrojni bili su izolirani među neprijateljski raspoloženim pravoslavnim stanovništvom. Smanjivanju broja vjernika pridonijelo je i opće raseljavanje iz Vrlike neovisno o vjeri. Konačni udarac ionako malobrojnoj zajednici u prvoj polovici 20. stoljeća bilo je neimenovanje novog župnika nakon smrti Ilije Malića, nego je župom upravljao administrator iz jedan dan hoda udaljenih Kričaka.

Iako nema vjernika, župnika, crkve ni župne kuće, grkokatolička župa Svete Trojice u Vrlici nikad nije ukinuta. Svećenik Milan Stipić zadužen je za Dalmatinski vikarijat Križevačke eparhije.

\section{Literatura:}

Anon. Stojdraški župnici. URL: http://free-zg.htnet.hr/stojdraga/ostalo.htm (12.09.2017.) Anon. (2012a). Biskup Đuro Smičiklas. U: Udruga Uskok Sošice. [Potpisano: admin.] URL: http://uskok-sosice.hr/biskup-duro-smiciklas/ (11.09.2017.)

Anon. (2012b). Sjećanje na svećenika Janka Herakovića. U: Udruga Uskok Sošice. [Potpisano: admin.] URL: http://uskok-sosice.hr/sjecanje-na-svecenika-janka-herakovica (11.09.2017.) 
Anon. (2012c). Žumberački svećenik Petar Stanić. U: Udruga Uskok Sošice. [Potpisano: admin.] URL: http://uskok-sosice.hr/zumberacki-svecenik-petar-stanic/ (12.09.2017.)

Barbić, Ivan (1898). Vrlički Hrvati odgovaraju piscu X. „Vrlike u borbi“: Napisao i uredio Y. Split: Narodna tiskara.

Bogović, Mile (1982). Katolička Crkva i pravoslavlje u Dalmaciji za mletačke vladavine. Zagreb: Kršćanska sadašnjost.

Draganović, Krunoslav (prir.) (1939). Opći šematizam Katoličke crkve u Jugoslaviji: Prema mandatu preč. Episkopata Jugoslavije izradio Dr. Krunoslav Draganović. Sarajevo: Izdanje Akademije Regina Apostolorum - Nova tiskara Vrček i dr.

Jelovina, Dušan (1976). Starohrvatske nekropole na području između rijeka Zrmanje i Cetine. Split: Čakavski sabor.

Kozlica, Ivan (2015). Vrličko pitanje: Vrlika u žrvnju velikosrpske politike. Trilj: Grad Vrlika - Kulturno društvo Trilj.

Milaš, Nikodim (1989). Pravoslavna Dalmacija. Beograd: Sfairos. [Ćirilica.]

Pavkovič, Uroš (2014). Vikarijati. U: Križevačka eparhija. URL: http://www.krizevackaeparhija.com/index.php/ustanove/vikarijat (12.09.2017.)

Pavković, Ivan (1980). U susret velikom jubileju. Žumberački krijes, 1, 7.

Roca, Stevan (1962). Vjesnik, 324, 25.

Slijepčević, Đoko (1991). Istorija Srpske Pravoslavne Crkve II: Od početka XIX veka do kraja Drugog svetskog rata. Beograd: BIGZ. [Ćirilica.]

Šematizam Križevačke eparhije, 1838, 1840, 1841, 1846, 1850, 1851, 1852, 1854, 1859, 1868.

Šimrak, Janko (1925). Progon grkokatolika u Dalmaciji. Katolički list, 8 (26. veljače), 89-92.

Turudić, Ante (2009). Porušene i pomalo zaboravljene vrličke crkve. Vrličko kolo, 1 (11), 5.

\section{Arhivski izvori}

AKE. Arhiv Križevačke eparhije, 74/1874, 32/1876, 488/1882, 30/1885, 813/1887, 175/1887, 218/1887, 814/1887, 329/1888, 574/1888, 638/1888, 708/1890, 712/1890, 747/1890, 770/1892, 800/1892, 871/1895, 1063/1895, 728/1897, 742/1897, 467/1915, 534/1915, 1073/1919, 1074/1919, 473/1922, 784/1922, 1222/1923 i 2003/1927. 
Injati - A Brief History of the Holy Trinity Greek Catholic Parish in Vrlika Ivo Mišur*

Summary

Based on archival research findings, the article puts forth a historical-chronological view of events concerning the Greek Catholic Parish of the Holy Trinity in Vrlika since its foundation until its de facto extinguishment following World War II. This paper provides, for the first time, a detailed account of the movement of the parish population and a demographic analysis based on the plight of its souls in 1887. The article demonstrates that the decisions of provincial and imperial authorities affected their numbers. The reasons for the disappearance of this small religious community are explained in the conclusion.

Key words: Vrlika, Greek Catholics, Križevci eparchy, Church history, 19th century

* Ivo Mišur, mag.ing.mech., Quality Research Institute, Zagreb. Address: Gajeva 17, 10000 Zagreb, Croatia. E-mail: ivo.misur@gmail.com 